\title{
Retraction Note: Ras-ERK1/2 signaling contributes to the development of colorectal cancer via regulating $\mathrm{H} 3 \mathrm{~K} 9 \mathrm{ac}$
}

\author{
Peng Tian ${ }^{1 \dagger}$, Yanfei Zhu ${ }^{2 \dagger}$, Chao Zhang ${ }^{1}$, Xinyu Guo ${ }^{1}$, Peng Zhang ${ }^{1}$ and Huanzhou Xue ${ }^{3^{*}}$
}

\author{
Retraction Note: BMC Cancer 18, 1286 (2018) \\ https://doi.org/10.1186/s12885-018-5199-3
}

The Editor in Chief retracted this article because of significant concerns regarding a number of Figures presented in this work, which question the integrity of the data. Specifically, a number of images appear to be the same and rotated between Fig. 2C, 2D and 4D in this article, and Fig. 2 and 3 in an article published earlier by unrelated authors ([1], now retracted). In addition, it appears that one image was re-used between Fig. 2D and 4D within this article.

The Editor-in-Chief therefore no longer has confidence in the integrity of the data in this article.

The authors have not responded to any correspondence from the editor or publisher about this retraction.

\begin{abstract}
Author details
'Department of Gastrointestinal Surgery, Zhengzhou University People's Hospital (Henan Provincial People's Hospital), Zhengzhou 450003, China.

${ }^{2}$ Department of General Surgery, Wuxi People's Hospital of Nanjing Medical University, Wuxi 214023, China. ${ }^{3}$ Department of General Surgery, Zhengzhou University People's Hospital (Henan Provincial People's Hospital), No.7, Weiwu Road, Zhengzhou 450003, Henan, China.
\end{abstract}

Published online: 24 May 2021

\section{References}

1. Huang, S, Jin, A. ZIC2 promotes viability and invasion of human

osteosarcoma cells by suppressing SHIP2 expression and activating PI3K AKT pathways. J Cell Biochem. 2018;119:2248-57. https://doi.org/10.1002/ jcb.26387.

The original article can be found online at https://doi.org/10.1186/s12885018-5199-3.

* Correspondence: huanzhou0002@sina.com

${ }^{\dagger}$ Peng Tian and Yanfei Zhu contributed equally to this work.

${ }^{3}$ Department of General Surgery, Zhengzhou University People's Hospital (Henan Provincial People's Hospital), No.7, Weiwu Road, Zhengzhou 450003, Henan, China

Full list of author information is available at the end of the article

(c) The Author(s). 2021 Open Access This article is licensed under a Creative Commons Attribution 4.0 International License, which permits use, sharing, adaptation, distribution and reproduction in any medium or format, as long as you give appropriate credit to the original author(s) and the source, provide a link to the Creative Commons licence, and indicate if changes were made. The images or other third party material in this article are included in the article's Creative Commons licence, unless indicated otherwise in a credit line to the material. If material is not included in the article's Creative Commons licence and your intended use is not permitted by statutory regulation or exceeds the permitted use, you will need to obtain permission directly from the copyright holder. To view a copy of this licence, visit http://creativecommons.org/licenses/by/4.0/. The Creative Commons Public Domain Dedication waiver (http://creativecommons.org/publicdomain/zero/1.0/) applies to the data made available in this article, unless otherwise stated in a credit line to the data. 